\title{
Four cases of mesothelioma among Finnish anthophyllite miners
}

\author{
A Karjalainen, L O Meurman, E Pukkala
}

\begin{abstract}
Four cases of mesothelioma in a cohort of 999 Finnish anthophyllite miners and millers are described. Three deaths were due to pleural mesothelioma and one to peritoneal mesothelioma among the total of 503 male deaths up to 1991. All four patients with mesothelioma had had long term (13 to 31 years) exposure in anthophyllite mining and milling. The latency time from the onset of employment until diagnosis was 39 to 58 years. All four patients were smokers or ex-smokers and had asbestosis. In three of the cases the pulmonary fibre concentration and fibre type were analysed by transmission electron microscopy. High concentrations ( 270 to 1100 million fibres/g dry tissue) of anthophyllite fibres were detected. The anthophyllite fibres were thicker and had lower aspect ratios than the values reported for crocidolite fibres retained in the lungs of patients with mesothelioma.
\end{abstract}

(Occup Environ Med 1994;51:212-215)

Numerous reports from several countries have described cases or series of pleural and peritoneal mesotheliomas in relation to occupational exposure to various types and mixtures of asbestos. In 1960 Wagner and coworkers described 33 cases of pleural mesotheliomas in the neighbourhood of a crocidolite mine in South Africa. ${ }^{1}$ In later studies, mesotheliomas have been found after occupational exposure to crocidolite, amosite, tremolitic material, and chrysotile asbestos. ${ }^{2}$

In Finland, anthophyllite asbestos has been exceptionally widely used because of its domestic production from 1918-75, and special attention has been focused on the role of anthophyllite asbestos in the aetiology of mesothelioma. Anthophyllite fibres have induced mesotheliomas in animal experiments both after inhalation and intrapleural administration, ${ }^{2}$ but epidemiological studies have failed to firmly connect exposure to anthophyllite and mesothelioma in humans. In a cohort of about 1000 anthophyllite miners and millers an increased risk of lung cancer was found, but no confirmed cases of mesothelioma were reported up to $1977 .{ }^{34}$ In a more recent study of 29 Finnish patients with mesothelioma, raised concentrations of anthophyllite fibres often occurred in their lungs, but usually together with other types of asbestos fibres. Anthophyllite fibres, never- theless, often constituted a large proportion of the total fibre burden and could therefore not be excluded as a cause of mesothelioma. In one of the patients with a reasonably low concentration of fibres only anthophyllite was detected. ${ }^{5}$

In this report we describe four cases of mesothelioma that occurred in the ongoing follow up of the cohort of Finnish anthophyllite miners and millers.

\section{Materials and methods}

THE COHORT OF ANTHOPHYLLITE MINERS Two anthophyllite asbestos quarries were worked in Finland during the period 1918-75. They were owned by the same company and located within $10 \mathrm{~km}$ of each other in a sparsely populated area about 50 $\mathrm{km}$ from the nearest city. The workers were recruited mainly from the farming population living in this area. In the 1950 s and 1960s the annual output was about 10000 tonnes. The quarries were combined with a dry hammer mill, which crushed, ground, and classified the broken rock into asbestos products for various industrial applications.

A fairly complete personnel register was kept by the company in the form of salary lists from 1936. The register contained the names, dates of birth, working periods, and roughly the kind of work done. The series of miners and millers included all workers employed for three months or longer between 1 January, 1936 and 1 July, 1967 (miners, millers, forestry workers, transportation workers, and office workers). After the exclusion of workers who could not be identified, the follow up was completed in 999 workers up to the end of 1991. The deaths in the cohort were researched through the death files of Statistics Finland. The deaths from cancer were based on the files of the Finnish Cancer Registry.

\section{HISTOLOGICAL VERIFICATION OF THE} DIAGNOSES

In all four cases of mesothelioma tissue samples taken from the tumour at necropsy or thoracotomy were available for histopathological examination. The diagnoses of mesothelioma were confirmed by the Finnish Mesothelioma Panel. Formalin-fixed and paraffin embedded tissue blocks were used in light microscopical histopathological, and immunohistochemical examination. In one of the cases (case 2 in table 1) a morphologically typical pleural mesothelioma with sarcoma- 
Table 1 Age, tumour type, exposure, and lung fibre concentration in the four cases of mesothelioma among Finnish anthophyllite miners

\begin{tabular}{llllllll}
\hline Case No & $\begin{array}{l}\text { Age at } \\
\text { diagnosis }\end{array}$ & Tumour type & $\begin{array}{l}\text { Tumour } \\
\text { location }\end{array}$ & $\begin{array}{l}\text { Year of } \\
\text { diagnosis }\end{array}$ & Years in mining & $\begin{array}{l}\text { Fibre concentration } \\
\text { in lung tissue } \\
\text { (million fibres/g) }\end{array}$ & $\begin{array}{l}\text { Fibre types } \\
\text { detected }\end{array}$ \\
\hline 1 & 82 & Epithelial & Peritoneal & 1989 & $31,1936-67$ & 1100 & Anthophyllite \\
2 & 75 & Sarcomatous & Pleural & 1987 & $13,1929-56$ & 270 & Anthophyllite \\
3 & 57 & Sarcomatous & Pleural & 1986 & $28,1947-75$ & 1100 & Anthophyllite \\
4 & 62 & Epithelial & Pleural & 1991 & $23,1950-75$ & - & - \\
\hline$-=$ No sample & & & & &
\end{tabular}

tous histology remained negative in cytokeratin staining and a sarcoma could not be completely excluded.

\section{ANALYSES BY ELECTRON MICROSCOPY}

In three cases a sample of lung tissue was available for analysis of the retained mineral fibres by electron microscopy. In one of these cases (case 2 in table 1) the tissue was stored in $4 \%$ formalin. In the two other cases the specimens were embedded in paraffin, which was subsequently dissolved with xylene. As the tissue weight is known to decrease during the process of embedding due to the extraction of lipids, ${ }^{6}$ the fibre concentrations of the paraffin embedded samples were corrected assuming a dry weight loss of $20 \%$.

A piece of tissue of about $100 \mathrm{mg}$ wet weight was taken for the fibre analysis. The samples were prepared according to a previously described method, ${ }^{5}$ which included low temperature ashing of the lung tissue and filtration of the remaining ash on polycarbonate filters. The filters were further coated with carbon and placed on electron microscopy grids. The filter material was dissolved with chloroform in a modified Jaffe washer. The fibres were counted with a JEOL $100 \mathrm{CX}$ ASID4D electron microscope in STEM mode on a CRT screen. An acceleration voltage of $100 \mathrm{kV}$ and a magnification of 15000

Table 2 Dimensions of anthophyllite fibres in the lungs of three cases of mesothelioma among Finnish anthophyllite miners

\begin{tabular}{|c|c|c|c|}
\hline Case No & 1 & 2 & 3 \\
\hline \multicolumn{4}{|c|}{ Fibre length $(\mu \mathrm{m})$ : } \\
\hline Range & $0 \cdot 80-27$ & $0 \cdot 70-44$ & $0 \cdot 80-31$ \\
\hline Mean & & & \\
\hline Median & $4 \cdot 1$ & 3.9 & $5 \cdot 1$ \\
\hline \multicolumn{4}{|c|}{ Distribution of } \\
\hline$<1.0$ & 4 & 2 & 4 \\
\hline $1 \cdot 0-4.9$ & 50 & 55 & 44 \\
\hline $5 \cdot 0-9 \cdot 9$ & 26 & 14 & 29 \\
\hline$\geqslant 10$ & 20 & 29 & 23 \\
\hline \multicolumn{4}{|c|}{ Fibre width $(\mu \mathrm{m})$ : } \\
\hline Range & $0 \cdot 05-1 \cdot 1$ & $0.06-1.5$ & $0.05-1.5$ \\
\hline Mean & 0.35 & 0.40 & 0.45 \\
\hline Median & $0 \cdot 30$ & 0.35 & 0.35 \\
\hline \multicolumn{4}{|c|}{ Distribution of } \\
\hline$<0.1$ & 13 & 8 & 9 \\
\hline $0 \cdot 1-0.49$ & 56 & 62 & 56 \\
\hline $0.5-0.99$ & 30 & 27 & 25 \\
\hline$\geqslant 1.0$ & 1 & 3 & 10 \\
\hline \multicolumn{4}{|c|}{ Aspect ratio (length/width): } \\
\hline Range & $3 \cdot 0-100$ & $3 \cdot 0-180$ & $3 \cdot 1-77$ \\
\hline Mean & 21 & 25 & 19 \\
\hline Median & 14 & 17 & 15 \\
\hline \multicolumn{4}{|c|}{ Distribution of } \\
\hline$<10$ & 32 & 34 & 33 \\
\hline $10-49$ & 59 & 55 & 63 \\
\hline $50-99$ & 8 & 8 & 4 \\
\hline$\geqslant 100$ & 1 & 3 & 0 \\
\hline
\end{tabular}

were used. All inorganic particles having roughly parallel sides and a length to width ratio greater than three were defined as fibres and counted. The dimensions of the fibres were measured directly on the screen with magnifications up to 100000 . The dimensions of 100 fibres per sample were measured.

An energy dispersive $x$ ray microanalyser (Tracor TN 5500) was used to identify the mineral type of each fibre. The intensity ratios of $\mathrm{Si}, \mathrm{Mg}, \mathrm{Fe}, \mathrm{Ca}$, and $\mathrm{Na}$ were used in the identification by comparing the spectra peak ratios to standard spectra. Four hundred fibres per sample were identified. This gave an analytical sensitivity of $<0.25 \%$ for fibre types other than anthophyllite. According to Poisson statistics this equals a detection limit of $<1.0 \%$ (four times the analytical sensitivity).

\section{Results}

In a recent follow up of 999 anthophyllite miners and millers, a total of 593 deaths (503 men and 90 women) were noted up to the end of 1991; 72 of these were were due to lung cancer, four to mesothelioma, and 31 to asbestosis. The diagnosis of asbestosis was mentioned in $20 \%$ of all death certificates. A detailed report on the incidence of cancer in this cohort is under preparation.

Table 1 presents the pathological characteristics of the four mesotheliomas and the exposure data of the patients. Three of the workers had pleural and one had peritoneal mesothelioma (one of the pleural mesotheliomas had also invaded the abdominal cavity). All four were male smokers or ex-smokers and had asbestosis. The three cases with available lung tissue samples had a very high concentration of anthophyllite fibres in their lungs; about $1 \%$ of the fibres were coated asbestos bodies. When 400 fibres per sample were identified, only anthophyllite fibres were detected. Numerous talc particles were also detected in the samples.

All four patients had had long term (13 to 31 years) exposure in the mining of asbestos (see table 1). The occupational histories indicated no exposure to asbestos other than in the Paakkila mine. As well as work in the Paakkila mine, all four had worked in farming and forestry. They all retired when they left the company. The latency time from the onset of employment to the diagnosis was 39 to 58 years. They all had lived in the neighbourhood of the mine before the onset of employment.

Table 2 summarises the measured sizes of 
the anthophyllite fibres in the three cases. The dimensions were similar. The median lengths of anthophyllite fibres were 3.9 to $5 \cdot 1 \mu \mathrm{m}$ with $20 \%$ to $29 \%$ of fibres exceeding $10 \mu \mathrm{m}$ in length. The median aspect ratios were around 20 , and $4 \%$ to $11 \%$ of the fibres had aspect ratios exceeding 50 .

\section{Discussion}

Four histologically confirmed mesotheliomas were found among 503 male deaths up to 1991 in a cohort of 999 anthophyllite miners and millers. There were no mesotheliomas among the 90 female deaths during the same period. In men, the proportion of deaths from mesothelioma (about $0.8 \%$ of all male deaths) was less than the $1.5 \%$ to $18.6 \%$ that have been reported in cohorts exposed to crocidolite, amosite, tremolite, or mixtures containing these amphiboles. ${ }^{7}$ The proportional mortality ratios obtained in different studies might, however, not be comparable-for example, because of different age structure of the person-years in the follow up. For comparison, the proportional mortality of mesothelioma in the Finnish male population in 1982-91 according to the statistics of the Finnish Cancer Registry was $0 \cdot 1 \%$. About $70 \%$ of deaths from mesothelioma in the Finnish population are related to occupational exposure to asbestos, mainly in shipbuilding, construction, and maintenance occupations. ${ }^{5}$ Additional deaths from mesothelioma in our cohort cannot be completely ruled out, as only $30 \%$ of the death certificates were based on necropsy, and pulmonary and abdominal malignancies were included among the cases that were not necropsied. The diagnostics of mesothelioma have also greatly improved in Finland during the past two decades. Therefore the accuracy of death certificates in the anthophyllite cohort up to the 1970s may not be comparable with the data of the general population in the 1980s.

Despite these epidemiological problems, it seems likely that although anthophyllite fibres can induce mesotheliomas in humans, they are less potent than crocidolite or amosite fibres. This might be related to the differences in the dimensional characteristics between anthophyllite, crocidolite, and amosite fibres.

A model for the carcinogenic potency of a fibre as a function of its size has been presented with the conclusion that long, thin fibres are more carcinogenic and fibrogenic than short and thick fibres, but many short fibres may induce a tumour as easily as a few long fibres. ${ }^{8}$ It has been suggested that fibres $8 \mu \mathrm{m}$ in length and $<0.2 \mu \mathrm{m}$ in width (aspect ratio greater than 40 ) are the most important in the causation of mesotheliomas in humans. ${ }^{9}$ The fibrogenic potential of asbestos fibres has been considered to correlate with the total surface area of retained fibres independently of fibre type. ${ }^{10}$ Anthophyllite fibres are on the average much thicker than crocidolite or amosite fibres. ${ }^{11}$ In a recent study of
29 Finnish patients with mesothelioma, the dimensions of fibres found in the lung tissue were measured with the same method as in our study. ${ }^{5}$ In that study, the crocidolite and amosite fibres were thinner (median width $0.06 v 0.35 \mu \mathrm{m}$ ) and had greater aspect ratios (median $30.0 v 14.2$ ) than anthophyllite fibres. The size of the anthophyllite fibres (median length $5.0 \mu \mathrm{m}$, width $0.35 \mu \mathrm{m}$ and aspect ratio 14.2) was in accordance with our results (table 2). These median widths are smaller than the $0.61-0.73 \mu \mathrm{m}$ in the earlier report on Finnish anthophyllite miners, ${ }^{11}$ probably due mainly to the poorer resolution of thin fibres at the lower magnification $(1500 \times)$ used in that study.

As well as cohorts exposed in mining or handling of asbestos, mesotheliomas have been reported among talc miners, whose exposure could have included fibrous tremolite. ${ }^{72}$ Tremolite has also been detected in geological investigations in the Paakkila area, but the amount of fibrous tremolite has not been documented. ${ }^{13}$ Exposure to fibrous tremolite among the Paakkila miners is therefore geologically possible. No tremolite fibres were, however, detected among the 400 identified fibres per sample in the lung specimens in our study. Neither has tremolite been reported as a contaminant in the International Union against Cancer (UICC) anthophyllite standard derived from the Paakkila mine, ${ }^{1415}$ nor detected in products or dust samples collected at the mine and mill, and analysed in our laboratory. Exposure to fibrous tremolite among the Paakkila miners is therefore, if not nil, probably very low.

The concentrations of fibres found in the lungs of the anthophyllite miners were very high. In Finland, with the same microscopy method, similar concentrations have been reported only among asbestos sprayers and shipyard workers exposed mainly during asbestos spraying (mostly crocidolite), ${ }^{5}$ and an increased risk of mesothelioma (OR 14.4, $90 \%$ confidence interval $2 \cdot 5-178$ ) has been associated with fibre concentrations exceeding 1 million fibres/g. ${ }^{16}$ All our patients were heavily exposed and had asbestosis. This might be related to the potency of anthophyllite fibres to induce mesothelioma; a reasonably high level of exposure is needed for a sufficient amount of fibres of adequate dimensions to be deposited in the lungs.

We express our sincere thanks to Kari Karkola MD, Timo Romppanen $\mathrm{MD}$, and Helena Malinen $M D$ who helped in obtaining the tissue material, to the Finnish Mesothelioma Panel (Sisko Antrila MD Tauno Ekfors MD, and Eero Taskinen MD) for their aid in the verification, and Eero noses, and to Terttu Kaustia MA, who did the linguistic revision of the manuscript.

1 Wagner JC, Sleggs CA, Marchand P. Diffuse pleural mesothelioma and asbestos exposure in the North Western Cape Province. Br F Ind Med 1960;17:260-71.

2 International Agency for Research on Cancer. Asbestos. Overall evaluations of carcinogenicity: an updating of $I A R C$ Overall evaluations of carcinogenicity: an updating of LARC monographs. Vols 1-42.

3 Meurman LO, Kiviluoto R, Hakama M. Mortality and morbidity among the working population of anthophyllite asbestos miners in Finland. $\mathrm{Br} f$ Ind Med 1974;31:105-12. 
4 Meurman LO, Kiviluoto R, Hakama M. Combined effect of asbestos exposure and tobacco smoking on Finnish anthophyllite miners and millers. Ann NY Acad Sci 1979;330:491-5.

5 Tuomi T. Fibrous minerals in the lungs of mesothelioma patients. Comparison between data on SEM, TEM and personal interview information. $A m \mathcal{F}$ Ind $M e d$ 1992;21:155-62.

6 Roggli LV, Pratt PC, Brody AR. Asbestos content of lung tissue in asbestos associated disease: a study of 110 cases. Br F Ind Med 1986;43:18-28.

7 McDonald AD, McDonald JC. Epidemiology of malignant mesothelioma. In: Antman $\mathrm{K}$, Aisner J, eds. Asbestos related malignancy. Boston: Grune and Stratton, Asbestos related

8 Pott F. Animal experiments on biological effects of mineral fibres. In: Wagner JC, ed. Biological effects of mineral eral fibres. In: Wagner JC, ed. Biol

9 Stanton MF, Layard M, Tegris A, Miller E, May M, Morgan E, Smith A. Relation of particle dimension to carcinogenicity in amphibole asbestos and other fibrous minerals. $\mathcal{F}$ Natl Cancer Inst 1981;67:965-75

10 Timbrell V, Ashcroft T, Goldstein B, Heyworth F, Meurman LO, Rendall REG, et al. Relationships between retained amphibole fibres and fibrosis in human lung tissue specimens. Ann Occup Hyg

11 Timbrell V. Deposition and retention of fibres in the human lung. Ann Occup Hyg 1982;26:347-69.

12 Kleinfeld M, Messite J, Kooyman O, Zaki MH. Mortality among talc miners and millers in New York State. Arch Environ Health 1967;14:663-7.

13 Aurola E, Vesasalo A. On the asbestos occurrences in Finland and their technical use. Helsinki: Geological Survey of Finland, 1954. (In Finnish with English summary.)

14 Rendall REG. The data sheets on the chemical and physical properties of the UICC standard reference samples. In: Shapiro A, ed. Pneumoconiosis, Proceedings of the International Conference fohannesburg 1969. London: International Conference fohannesbur

15 Timbrell V. Characteristics of the International Union Against Cancer standard reference samples of asbestos. In: Shapiro A, ed. Pneumoconiosis, Proceedings of the International Conference fohannesburg 1969. London: Oxford University Press, 1970:28-36.

16 Tuomi $T$, Huuskonen $M$, Virtamo $M$, Tossavainen $A$ Tammilehto L, Mattson $\mathrm{K}$, et al. Relative risk of mesothelioma associated with different levels of exposure to asbestos. Scand $f$ Work Environ Health 1991;17:404-8. 